Portland State University

PDXScholar

Summer 2021

\title{
The Diminishing Power and Democracy of Hong \\ Kong: An Analysis of Hong Kong's Umbrella \\ Movement and the Anti-Extradition Law Amendment Bill Movement
}

Xiao Lin Kuang

Portland State University

Follow this and additional works at: https://pdxscholar.library.pdx.edu/honorstheses

Part of the Asian Studies Commons, and the Other International and Area Studies Commons Let us know how access to this document benefits you.

\section{Recommended Citation}

Kuang, Xiao Lin, "The Diminishing Power and Democracy of Hong Kong: An Analysis of Hong Kong's Umbrella Movement and the Anti-Extradition Law Amendment Bill Movement" (2021). University Honors Theses. Paper 1126.

https://doi.org/10.15760/honors.1157

This Thesis is brought to you for free and open access. It has been accepted for inclusion in University Honors Theses by an authorized administrator of PDXScholar. Please contact us if we can make this document more accessible: pdxscholar@pdx.edu. 
The diminishing power and democracy of Hong Kong: an analysis of Hong Kong's Umbrella Movement and the Anti-extradition Law Amendment Bill Movement

by

Xiao Lin Kuang

An undergraduate honors thesis submitted in partial fulfillment of the

Requirements for the degree of

Bachelor of Arts

In

University Honors

And

International Development Studies

And

Chinese

Thesis Adviser

Maureen Hickey

Portland State University 


\section{Abstract}

The future of Hong Kong - one of the most valuable economic port cities in the world - has been a key political issue since the Opium Wars (1839-1860). After eight five years of being a British colony, Hong Kong was returned to mainland China in 1997 under a special arrangement that was intended to preserve Hong Kong's special political and administrative status until 2047. As Hong Kong is a special administered zone, it utilizes a democratic governing system and enjoys freedoms that mainlander citizens of China do not experience. Many scholars have warned Hong Kong of its dire position politically as China continues to open up the mainland for foreign businesses. In this thesis, I argue that China never intended to honor the agreement of democracy with Hong Kong until 2047, as Hong Kong is can only be as politically troublesome as it is economically useful to the Chinese Communist Party (CCP). Through the analysis of China's increasing political presence in Hong Kong, the diminishing freedoms of Hong Kong people, and the lack of Hong Kong's economic success in both the gross domestic product (GDP) and stock market exchange platforms in comparison to the mainland, I found that Hong Kong is no longer as important to the Chinese government as it once was during the 1997 turnover. Hong Kong waited too long to attempt to break free from communist rule. Hong Kong's title as a global financial hub will likely not give the island any advantage over the mainland cities nor will it receive any more favoritism from the CCP. China will continue to bring Hong Kong in line with the rest of the country and as a result, Hong Kong's freedoms as well as its special administered zone status can cease to exist completely in the future.

Keywords: Hong Kong, Hong Kong 2019 Protest, Umbrella Movement, Anti-Extradition Law Amendment Bill Movement, Hong Kong prodemocracy, China special economic zones (SEZs) 


\section{Introduction}

Hong Kong has been under political conflict since the Opium Wars and the Unequal Treaty Era (1839-1899), as the island went from a Qing Dynasty port city to British eastern colony (1842-1997), and finally a special administrative zone of China's Communist Party (CCP) (1997-present) (Hoare, 2000). While Hong Kong does belong to the CCP, the special administered zone utilizes a democratic governing system and enjoys freedoms that mainlander citizens of China do not experience, such as freedom of speech and press. These characteristic sets Hong Kong as one of the most valuable and popular economic port cities in the world to investors. Learning from the success of Hong Kong and Taiwan, the CCP opened up the mainland for foreign businesses as well. After analyzing China's economic plan, many scholars have warned Hong Kong of its dire position politically when China's economic power outshines that of Hong Kong's someday. That time of such an economic power dynamic has arrived for Hong Kong. Understanding the weak political position of Hong Kong in 2021 is crucial for several reasons. First, Hong Kong is not only a crucial world financial hub for many western superpowers (i.e. United States (US)), but is the only Chinese city to have strong relations with foreign nations (i.e. Britain (UK)). Second, it is the only city in China to have access to information outside of China's Great (Internet) Firewall (without a virtual private network (VPN)), which means the city is less likely to have propaganda influences. Third, the governing system of Hong Kong is democratic and gives the people freedoms not enjoyed by the rest of China. This is a key attractor for foreign business investors and can easily affect the development and value of global companies-not just western ones. Fourth, Hong Kong's success or failure of democracy is a key factor in how China reflects itself as an official superpower to the rest of the world. In light of recent and ongoing protests for autonomy and the preservation of democracy, Hong Kong has shown to reach a stage of no return, in other words, Hong Kong will continue to face more freedoms taken away by this power dynamic, while those 
freedoms already taken would not be returned. China will truly be a single political party with no interference from western countries and become a recognized superpower.

To explore these issues, first, I will provide a background on the Opium Wars and Hong Kong's governing system in comparison to mainland China's communist system. Following the background, I explain my methods of research as well as a literature review. The literature review consists of an analysis of the democratic differences between Taiwan and Hong Kong, Hong Kong's democratization challenges with the Chinese Communist Party (CCP), and the necessity of Hong Kong to keep its political independence. My thesis is that China never intended to honor the agreement of democracy with Hong Kong until 2047 and Hong Kong waited too long to attempt to break free from communist rule. In support of this argument, I first examine China's increasing political presence in Hong Kong, then the diminishing freedoms of Hong Kong people, and finally Hong Kong's gross domestic product (GDP) and stock market exchange platforms in comparison to the mainland. I conclude with a consideration of Hong Kong's diminishing freedoms and lack of economic success in comparison to the mainland, that Hong Kong is no longer as powerful nor as important to the Chinese government as it was at the time of the handover. The democracy of Hong Kong can and will be erased by the CCP in time.

\section{Background}

\section{Opium Wars and the era of Unequal Treaties}

While British Imperialism began earlier than the nineteenth century, one of the greatest global trade expansions was during that time. The British, French, and Spanish led fleets to conquer new colonies and extract wealth. As trade brought beneficial discoveries to the imperial powers, it also created centuries of damage to conquered cultures and societies. An important case-in-point is that of the Opium Wars between China and Great Britain. After the First Opium War, from September $4^{\text {th }}, 1839$, to August 29, 1842, Britain forced China to sign the Treaty of Nanjing, which ceded the island of Hong 
Kong to the British. The British colony flourished as an East-West trading center, commercial gateway, and distribution center. Hong Kong made an excellent easy access port for the British traders to connect with East-West traders from various East Asian countries. Hong Kong served as a colony so well that after the Second Opium War (June $28^{\text {th }}, 1856$ to October $\left.18^{\text {th }}, 1860\right)$, Britain decided they wanted the island longer and in 1898, under the Second Convention of Peking, China was forced to cede the Kowloon Peninsula, adjacent to Hong Kong Island, along with other area islands to Britain for an additional ninety-nine years of ruling (History.com Editors, 2010). It wasn't until September of 1984, after years of negotiation between the two nations, that the British agreed to sign a formal agreement for the 1997 turn-over of Hong Kong in exchange for the pledge of allowing Hong Kong to keep its capitalist system and democratic political structure (people have to right to vote for government representatives). At midnight on July $1^{\text {st }}, 1997$, Hong Kong was finally peaceably returned to China after 156 years. The problem of returning a long-lost child such as Hong Kong was that it no longer recognized the authority of its 'mother'. Citizen of Hong Kong and mainland China saw each other as distant relatives. Hong Kong people saw the Mainlanders as uncivilized beings and the mainland to be less developed than the island. This could be due to a social norm introduced by the British Imperialists or that Hong Kong people viewed that the advantage of Hong Kong's rapid economic growth and urban development meant their status is also above the mainland people. In addition, many Hong Kong people have gotten used to the governing system of democracy rather than communism, which led some Hong Kong people to believe that China's governing system is not as advanced as that of Hong Kong's (Wang and Dong, 2021).

To understand the pollical disconnect between Hong Kong and mainland China, we also need to look to China's tumultuous history. When Hong Kong was 'given' to Britain in 1842 and again in 1898, China was still under the rule of the Qing Dynasty. The Qing Empire ruled China from 1644 to 1912, with the last emperor, Puyi, being overthrown by the Chinese Revolution or also known as the Xinhai 
Revolution in 1911. As a result, on January $1^{\text {st }}, 1912$, the Republic of China was established. Immediately following World War II, China had an internal political war between two parties, the Chinese Communist Party (CCP) and the Nationalist Party (as known as Kuomintang (KMT)) (Office of the Historian, 2021). This political war that preceded on and off since the 1920's finally ended by Mao Zedong, the Chinese Communist leader, in 1949. This Chinese milestone that ended the political war came to be known as The Chinese Revolution of 1949. Based on a single political party system grounded in Marxist and based initially on the Soviet principles of a communist state, Mao Zedong, the founding father of the People's Republic of China (PRC), redefined China's agriculture and industrial system (The Editors of Encyclopaedia Britannica, 2020).

In December 1978, Deng Xiaoping, the successor to Mao, shifted away from Mao's vision of a "Red China" and created the new Open-Door Policy that allowed foreign business to set up in China, which became the turning point in China's economic future as the "world's factory" (Bajpai, 2021). Since the Open-Door Policy enacted, the Chinese economy has grown aggressively, as a result of export-led growth and with the support of the CCP and the Chinese state apparatus (van Kemenade, 1998). Then, affter forty-eight years of communist rule, China reclaimed Hong Kong Island from Britain. The transition has been rocky and filled with uncertainty for the citizens of Hong Kong; as can be seen by the large number of pro-democracy protests both before and since the 1997 handover. These democracy protests include: the Tiananmen Solidarity Protests (1989), Anti-Article 23 Protest (also known as The July 1 Protest Rally) (2003), the Anti-moral and National Education Movement (2012), the Umbrella Movement (2014), and the most recent Anti-Extradition Law Amendment Bill Movement (also known as the 2019 Protest) (2019-2021). Of the protests mentioned above only the Anti-Article 23 Protest and the Anti-moral and National Education Movement had been successful (Duhalde and Huang, 2019). The Anti-Extradition Law Amendment Bill Movement's success or failure is still yet to be determined, but the chance for success is low. Since China had no intentions of giving Hong Kong the freedoms it had under 
the British rule, Hong Kong remains only as important as its economic importance is to China. For the purpose of being concise, I briefly review the significance of the Anti-Article 23 Protest in the literature review section, while in the research section I use the two most recent democracy protests of Hong Kong, the Umbrella Movement (2014) and Anti-Extradition Law Amendment Bill Movement (20192021), to analyze this economic power dynamic between China and Hong Kong.

\section{Hong Kong's governing system}

Of course, to understand the difference between the communist governing system in the PRC and Hong Kong's democratic governing system is it necessary to first analyze how the island's governing body is organized. While Hong Kong was a Britain colony, the island was administered by a governor, who was appointed by, and represented, Britain's monarch. The governor directed the government and served as the commander in chief as he presided over the Executive Council and the Legislative Council (Britannica, 2020). Under the constitutional agreement signed by both countries, the Basic Law, Hong Kong is to be administered as an autonomous Special Administrative Region (SAR) of the People's Republic of China except in the case of defense and foreign affairs. Britain's hope was that this special authority for Hong Kong would help the island people to adjust slowly back into Chinese rule. Hong Kong's autonomous status as a SAR was to last for 50 years (until 2047) -following the handover in 1997. The two-tiered system allows a representative government to exist with an independent judiciary (GovHK, 2020).

The Chief Executive, head of the HK SAR, is elected by a broadly representative Election Community which is appointed by the Central People's Government (Mainland China). The Executive Council serves no longer than the Chief Executive's term of office, assists the Chief Executive in policymaking, and comprises 16 principle officials and 16 non-official members. These members are appointed by the Chief Executive, members of the Legislative Council, and public figures. The HK 
government's main administrative and executive functions of government are carried out by 13 policy bureau and 56 departs which employs approximately 174,900 people (4.4 percent of the HK workforce). The law-making body of the SAR is the Legislative Council that consists of 70 members of which 35 are directly elected by geographical constituencies and the other 35 elected by functional constituencies. However as of May 27, 2021, Hong Kong's legislature passed an electoral reform bill that allowed Beijing more power to appoint and remove lawmakers on Hong Kong's legislative council, while reducing the number of seats elected by the public. Hong Kong's legislature now has 90 total seats of which 40 are elected by a pro-Beijing committee and only 20 seats to be directly voted by the public (DW News, 2021). With 20 seats, the public can vote less than a quarter of the total seats in the legislative council. The Legislative Council's purpose is to debate issues of public interest, examine budgets, debate the Chief Executive's policies, endorse the appointment and removal of the judges of the Court of Final Appeal and the Chief Judge of the High Court. HK is split into 18 districts with 458 members on the District Council (431 elected members, 27 ex officio members). They serve for 4 years to address improvement projects, promote recreational projects, cultural and community activities, advise the government on matter that affect the well-being of residents such as the adequacy and priorities of government programs. Last but not least, the Judiciary ensures that Hong Kong remains within the common law system, therefore the department is independent from the legislative and executive branches. The Court of Final Appeal is the highest of the courts headed by the Chief Justice (GovHK, 2020).

This is significant as we compare the democratic nature of this system with the government operations of the PRC. Unlike Hong Kong, mainland China is governed by a small population as opposed to the opinions of the majority. There are no voting rights given to the public. The Communist Party consists of around 91.91 million members while China's population is 1400.05 million as of 2019 (Xinhua News Agency, \& State Council Information Office (China), 2021; IMF, \& National Bureau of Statistics of 
China, 2021). This means that less than $7 \%$ of the population controls the entire nation. The Chinese Communist Party consists of a pyramid structure with Xi Jinping (current chairman of the CCP) at the top, then followed by The Party (also known as the Politburo Standing Committee), which consists of six standing committee members and eighteen members with high government roles/ titles, and finally the National People's Congress at around 3000 members who write laws and supervise the government and the people (SCMP, 2021). This means that around $0.0000022 \%$ (3025 communist members with authority divided by the Chinese population of 1400.05 million) of the Chinese population actually get a voice of how China should be governed. Not only is the majority's opinion ignored, but that about one in sixteen mainlanders, hold nearly every top position in government, military, education, state-owned enterprises, health care, and banking (McMorrow, 2015). Undoubtedly, a glass ceiling exists and inequality surrounds mainland China. If Hong Kong is to lose its current democratic governing system, it in a way loses a sense of identity and equality.

\section{Research Question}

In this thesis I argue that China had minimal intentions of allowing Hong Kong to remain autonomous and democratic following the 1997 handover from British rule. As mainland China has ramped up its economic capacity and become a major international economic player, Hong Kong's ability to bargain to retain its special status has further diminished. Therefore, Hong Kong's recent protests have had, and will continue to have minimal impact on the PRC's plans to incorporate Hong Kong into the PRC. The current power dynamic between Hong Kong and mainland China is too imbalanced, in which China has much more power over Hong Kong now than the 1990s. The island had also waited too long to involve foreign powers for meaningful change towards their governing system. I argue that the ongoing Anti-Extradition Law Amendment Bill Movement (also known as the 2019 Protest) could have been anticipated based on past scholarly works. In addition, the ultimate outcome of this and future protest movements can also be predicted/ they will not succeed. The historical shift in 
the power dynamics between the mainland and Hong Kong is irreversible, in other words, Hong Kong will continue to have more freedoms taken away, and those freedoms already taken would not be returned. The main body of this thesis focuses on using Hong Kong's Umbrella Movement (2014) and the Anti-Extradition Law Amendment Bill Movement (2019-2021) as evidence of Hong Kong's decreasing freedoms and its decreasing economic importance to China.

\section{Methods}

Through this thesis I will analyze the power dynamic between Hong Kong and Mainland China through the lens of past scholarly works. I use scholarly books and articles published from the 1990s to present, however most of the utilized materials would be from sources of the 2000 s. In addition to scholarly articles, I have included news articles, news reports (media platforms), and public government archives to analyze the power dynamic of Hong Kong with China. I use a variety of news media from different countries and a variety of scholarly works from different publishers to provide a check against possible confirmation bias in my selection of source. As the Hong Kong protests for democracy continues, events may unfold differently, yet as of the completion of this thesis the articles used will be based off the most recently published information. The Umbrella Movement and the ongoing AntiExtradition Law Amendment Bill Movement will not be the last protests in Hong Kong. Given the history of intense protest since 1997, culminating in the current Anti-Extradition Law Amendment Bill Movement, it is likely that the fight for Hong Kong's democracy will carry on for years to come. In the following section of this paper the Umbrella Movement and the Anti-Extradition Law Amendment Bill Movement (also known as the 2019 Protest) is discussed in detail. Additionally, the historical events analyzed in this thesis will continue to have a profound impact on both the focus and the potential success or failure of future demonstrations.

\section{Literature Review}


First, many scholarly works discuss Taiwan's success under the "one country, two systems" policy, so it is important to acknowledge the 'Taiwan situation' here and how it has shaped scholarly and popular understandings of the PRC's relationship with Hong Kong. However, after careful consideration I argue that Taiwan is not a particularly useful comparative example in understanding the state of democracy struggles in Hong Kong today. Both Taiwan and Hong Kong have gone through democratic protests with police fighting against protesters and both islands were annexed to foreign nations after a war. However, clear differences can be seen between the two annexed islands. In 1895, China cedes Taiwan, among other territories to Japan after losing the First Sino-Japanese War (BBC News, 2019). The Chinese Kuomintang (KMT) government (with is opposing party to the CCP describe previously) renounces all treaties with Japan and demands the Taiwan be returned. As a post-war settlement, in 1943, the agreement of Taiwan's return was endorsed by the Allies in the Cairo Declaration. Finally, by 1945, the Allies place Taiwan under Chinese administrative control. When Mao Zedong led the Communist (CCP) to victory over the Kuomintang (KMT) in the Chinese Revolution of 1949, the Kuomintang government along with roughly two million refugees evacuated to Taiwan (BBC News, 2019). Following the 1951 San Francisco Peace Treaty signed by Japan and 48 Allied nations, the Japanese renounced all right, title, and claim to Taiwan, Penghu, the Spratly Islands, and the Paracel Islands (Ministry of Foreign Affairs Taiwan, 2021). While the PRC has continued to claim Taiwan as part of the PRC, they have not had actual control over the island politically since 1949, when the Kuomintang (KMT) took over Taiwan. Hence, Taiwan and Hong Kong's political situation is completely different. While Hong Kong is a British colony that was 'given back' to the CCP, Taiwan theoretically already belongs to the CCP but in practice is not governed in anyway by the CCP. Furthermore, Taiwan's currently has two main political parties, which is the KMT and the Democratic Progressive Party that was formed in 1986 because of the Kaohsiung Incident. In the following year, 1987, the Martial Law that went into effect since 1949, ended (which allowed family visits to mainland) and bans on the formation 
of the new political parties and news publications are lifted. Following the rise of democracy in Taiwan, the Republic of China Taiwan (ROC) held its first-ever direct presidential election (occurs every four years), in which the KMT's Lee Teng-hui and his running mate, Lien Chan, won with a majority at 54\% (Ministry of Foreign Affairs Taiwan, 2021). It wasn't until March 2000 that Chen Shui-bian, a Democratic Progressive Party candidate, won the presidential election. This ended the Kuomintang party's fifty-year monopoly of power. Since then the party ruling of Taiwan has been on and off between the Democratic Progressive Party and the Kuomintang (KMT) (BBC News, 2019).

In addition, it was under the KMT rule that Taiwan thrived economically. The creation of export processing zones, which started in 1966, allowed Taiwan to become a developed nation and set a paradigm for other countries to follow, with the first export processing zone in Kaohsiung city, southern Taiwan. Hong Kong thrived economically under the British rule as a colony port city rather than that of a specific zone. As Gilles Guiheux (Professor at the University of Paris) states, “Taiwan's 'economic miracle' has long been credited to the Guomindang [Kuomintang] state and to the strategies of foreign multinational corporations looking into the 1960 s for cheap labor... What is considered the real miracle... is how industrial production spread as far as almost every village of the country in a relatively short time" (Mengin and Rocca, 2002, p.187). It is under the Kuomintang (KMT) - not the CCP-rule that Taiwan prospered to its current economic ability. In 1997, Taiwan represented 33.10 percent of total sales on the national market of China. Professor Ran Wei from the School of Journalism and Communication in Hong Kong explains, "The [Taiwan] government attempted to balance considerations of political democratization (thus indigenization) with those of accommodation with mainland China... In [1993], the government further declared an end to the state of war with the People's Republic of China (PRC)" (Li, 2000, p.340). Taiwan did not choose to continue to challenge Beijing's power and kept its independence to a certain extent. The CCP tried to threaten and disrupt the 1996 elections with missile tests. For example, in May 2000, Taiwan president, Chen Shui-bian said in his inaugural speech that he 
will not declare independence as long as mainland China does not attack, nor will he call for a referendum on independence or abolish Taipei's (Taiwan's capital city) official blueprint for an eventual reunion with mainland China (BBC News, 2019). Therefore, unlike Taiwan, Hong Kong is vastly different in terms of political power and economic rise. The British ruled over Hong Kong for over a century. It is during this British colonization period that Hong Kong thrived economically, which gave it the world financial hub title. Therefore, Taiwan cannot be compared equally with Hong Kong in terms of their road to democracy nor their economic build.

Hong Kong University Professor Ming Sing's comparative analysis on Hong Kong's democratization suggests that through the period of 1980 to 2002, "the Chinese Communist Party (CCP) was the major force opposing Hong Kong's democratization... The CCP wanted economic liberalization without political liberalization in order to 'modernize' China and, at the same time, maintain its hegemony" (Sing, 2002, p.204). Hong Kong's rapid democratization would eventually become a subpolity of China and soon enough the CCP's interest would be threatened. For this reason, the CCP took many counter measures toward limiting the power of Hong Kong while taking control of the Hong Kong governing system from within. Professor of Hong Kong Studies at The University of Hong Kong, Yiu-wai Chu argues that "Hong Kong has been trouble by the anxiety of becoming another Mainland city [thus Hong Kong] took great pains branding itself into an 'international' city, which, ... led to its being lost in transition" (Chu, 2013, p.151). For a city as well defined in the global context to be 'lost in transition' is a major global issue. Phillip Bowring, columnist for the International Herald Tribune and consultant to Kleinwort Benson Securities Asia, notes that Hong Kong faces multiple challenges, but its biggest challenge is to perhaps "retain its own openness and accessibility." Hong Kong had been advantageous over Singapore due to "the freedom of the press and lack of politically driven constraints on social behavior" (Cohan and Zhao, 1997, p.23). If Hong Kong loses its democratic system, then the island's very identity would be taken away along with any advantages that come with it such as the attraction of 
foreign investors and foreign employment. Other scholarly works have analyzed the necessity of Hong Kong to keep its political independence, yet the island would face many challenges.

These challenges were already stated by even earlier published works such as Norman Miners's The government and politics of Hong Kong (1986), Frank Ching's Hong Kong and China: "one country, two systems"? (1996), and John Young's Precarious balance: Hong Kong between China and Britain (1994). These scholars warned Hong Kong of potential disputes as China rushed the process of Hong Kong's political transition. In 1998, Willem Van Kemenade, a journalist and correspondent for the major Dutch newspaper NRC Handelsblad published his book, China, Hong Kong, Taiwan, Inc., which also analyzed the anatomy and integration of China's "three systems," or simply put Mainland China, Hong Kong, and Taiwan. By opening old 'treaty ports' China hopes to accelerate its economic construction. Kemenade explains, "The creation of these zones was inspired partly by the pre-Communist experience of the old treaty ports, partly by the more recent worldwide experience of developing market economies, most of all Taiwan" (Kmemenade, 1998, p.161). While Taiwan in the 1960s had established three export processing zones and emerged as a major trading power by the early 1980s, China had yet to start its global trade. The treaty ports became Special Economic Zones (SEZs). According to Kmemenade, "To further China's dual goals of reintegration with Taiwan and Hong Kong and acceleration of outward economic development, four special economic zones (SEZs) were established in the southeastern coastal belt near Hong Kong and Taiwan" (Kmemenade, 1998, p.161). These zones became relatively successful, and today include Shengzhen, Zhuhai, Shantou, and Xiamen. Chinese Special Economic Zones vary in scope and function but made significant contributions to China's economic progress (World Bank, 2019). According to the China Development Bank, the different types of Chinese SEZs are administrative areas, geographical areas, international cooperation, local industrial parks, industry clusters, and corporate SEZs (World Bank, 2017). Hong Kong went from being a British colony to a Special Economic Zone (SEZ) of China, and now, at the start of the third decade of the 
twenty-first century, it is just one of many such SEZs. As China positions itself as a world power, it is increasingly confident in claiming and displaying that power, especially now that Hong Kong has lost its initial outsized important in growing the overall Chinese economy. As a consequence, the CCP has a strong interest in limiting Hong Kong's power even more as Hong Kong is no longer a key component to China's overall economic status.

More recent scholarly works have focused on Hong Kong's protests after 2000. On the first of July 2003, more than half a million people took to the streets to protest Beijing's new national security reform, as known as Article 23. Article 23 of the Basic Law states:

The Hong Kong Special Administration Region shall enact laws on its own to prohibit any act of treason, secession, sedition, subversion against the Central People's Government, or theft of state secrets, to prohibit foreign political organization or bodies from conducting political activities in the Region, and to prohibit political organizations or bodies of the Region from establishing ties with foreign political organizations or bodies (Cheng, 2005, p.1).

Anthony B. L. Cheung, professor at the City University of Hong Kong, explains that Hong Kong is in great political turmoil, "Article 23 came not just an issue about whether laws should be enacted to protect national sovereignty and security, but rather a perceived threat to political freedoms and civil rights presently enjoyed by Hong Kong people who regard them as part and parcel of the 'one country, two systems' deal" (Cheng, 2005, p.33). According to Professor Joseph Y.S. Cheung at the City University of Hong Kong, the $1^{\text {st }}$ of July 2003 Rally is different from the three major protest rallies in May-June 1989 during the Tiananmen Incident: first, Hong Kong people marched for a Hong Kong issue; second, with the Article 23 legislation and the issue of democratization, the pro-Beijing United Front had been fully mobilized in support of the Tung Administration (Cheng, 2005, p.2). Hong Kong was and still is on the verge of searching for a new Hong Kong identity. Mainland China and Hong Kong are on opposite ends 
of the grid of civilization, in other words, what is good and essential for Hong Kong's new generation is essentially lethal to Beijing's core values. Ching-tin Hung, Professor at the University of Hong Kong, notes the divide between the motherland and the island:

Both [mainland] officials and intellectuals shared the same despise and detest for Hong Kong's colonial status that was extended nearly 50 years after 1949. Above all, they see Hong Kong's freedom and individualism, equality and openness, pluralism and interactivity, rule of system and rule of law philosophically, an anathema to the Chinese ontology, and politically a continuation of the imperialist and colonialist to sabotage China after 1997 (Cheng, 2005, p.131).

This divide between the motherland and island had only gotten worse over time as Hong Kong's younger generations (the Millennials generation and forward) grew up with liberal values and expectation, in an international city outside of China's Great Firewall. Hence, most protests if not all recent protests are mostly composed of the members of the younger generations.

In 2014 the Umbrella Movement became Hong Kong's next most spectacular struggle for democracy. In this 79 day movement the protest marked "a significant episode for both new global activism and Hong Kong's political history" (Ma and Cheng, 2019, p.12). Ngok Ma (Associate Professor at the Chinese University of Hong Kong) and Edmund W. Cheng's (Associate Professor at the City University of Hong Kong) book, The Umbrella Movement: Civil Resistance and Contentious Space in Hong Kong, goes beyond the traditions of social movement studies and instead pay attention to the role of emotion and new agency in the protests. Ngok Ma states, "Years of conventional protests and bargaining had failed to bring about full democracy for Hong Kong. The rise of a new political identity and trends of radicalization in social and political movements [fueled] the massive civil disobedience campaign" (Ma and Cheng, 2019, p.27). The movement prompted the rise of a new political identity among the younger 
generation of Hong Kong. This trend towards radicalization in local movements is pushed by the younger generation's determination to have more say in their political future. Samson Yuen, Assistant Professor of Political Science at Lingnan University, demonstrates how "the city's hybrid regime adaptively switched its response from repression to attrition, after police repression catalyzed heightened mobilization" (Ma and Cheng, 2019, p.185). Yuen explains that this strategy of attrition entailed an array of defensive and offensive tactics that extended beyond ignoring protests. "The regime actively sought to maintain elite cohesion and block political opportunities while leveraging counter-movements and legal interventions to increase the participation cost of the protests and mobilize public discontent," says Yuen. For this reason, even with resistance from protesters ultimately the attribution strategy suggests an effective regime response and a flexible holder of tactics. The pro-regime mobilization of Hong Kong shows in 2011, there were 5 parades, in 2012 there were 4 demonstrations and parades, in 2013, there were 4 parades, 27 demonstrations, and 4 signature campaigns. In 2014, when the Umbrella Movement went into motion, there were 8 parades, 27 demonstrations, and 9 signature campaigns (Ma and Cheng, 2019, p.196). Chair Professor Yongshun Cai of social science at the Hong Kong University of Science and Technology, suggests that for protesting groups to achieve their desired effect they must need to carry out tactical escalation in order to empower their action. Cai explains that the public support is not the only thing that is considered in an effective tactical escalation (in terms of empowering their action), but that timing of the escalation reveals the essence of a movement's momentum. Therefore, Cai argues, "the tactical escalation of the Umbrella Movement proved to be ineffective because some tactics damaged the movement's image or were undertaken at a time when the momentum was already significantly low" (Ma and Cheng, 2019, p.209). Yongshun Cai showed how newspaper coverage of the Umbrella Movement from Apple Daily and Mingpao (News) went from over 120 articles in September 2014 to just below 20 articles in November 2014 (Ma and Cheng, 2019. p.220). 
Indeed, both the $1^{\text {st }}$ of July 2003 Protest Rally and the Umbrella Movement deem to be unsuccessful for Hong Kong's democratic movement against the CCP.

Regardless of the Umbrella Movement's success or lack thereof, many symbols and art forms used to symbolize the protests are still relevant in Hong Kong's fight for democracy including the iconic yellow umbrella that was used by protesters to repel police tear gas. Associate Professor Tai Wei Lim at the National University of Singapore analyzed the use of symbols, art, and aesthetics in the first phase of Hong Kong's 'Occupy Central' movement (the Umbrella Movement). Lim found that:

There is a limit to cultural soft power influence in effecting immediate change. If conflated with bread-and-butter issues, it can be a spark or accelerator of mass-based discontent. But if confined to a particular demographic and occupational group like the students in this first phase of the Revolution, transformative changes are unlikely... While transformative changes are unlikely, and foreign pressure is present but measure, the impact of the first phase of the Umbrella Revolution is mainly symbolic, cultural, and soft power persuasion (Lim, 2015, p.97).

The Umbrella Movement remains an iconic movement with much violence from the Central Government, however, the mark the revolution left behind can be said to be "an exercise in creating awareness, a generational... assertion of wants and desires and a long-term devotion to Hong Kong" (Lim, 2015, p.97).

Through these two major protest experiences the mainland Chinese authorities certainly know what Hong Kong is capable of during democratic demonstrations, but they are increasingly savvy about the kind of tactics necessary to efficiently degrade the movement's momentum for future political movements. In 1997, Michael Elliott and Dorinda Elliot journalists for Newsweek LLC notes, "the return of Hong Kong to China after 156 years of British rule symbolizes the decline of one economy and rise of another" (Elliot and Elliot, 1997). In their article, Why the world watches: how China treats Hong Kong 
will reveal its true face, they quote Michel Oksenberg, senior fellow at the Asia-Pacific Research Center at Stanford University in 1997, who argues, "Hong Kong is clearly a litmus test of China's capacity to adhere to international agreement... It will indicate what sort of power China is going to be" (Elliot and Elliot, 1997). The interest of Hong Kong's political movements are not just a matter of commercial interests or human rights. Ming Sing, Associate Professor at the City University of Hong Kong, suggests that Beijing will continue to face challenges to address the younger generation's aspirations of democracy and greater propensity to join civil disobedience movements (Ma and Cheng, 2019, p.233).

2019 marked the start of the most recent and controversial democracy protest in Hong Kong's post-1997 history. Hong Kong's Anti-Extradition Law Amendment Bill Movement continues to go on at the time of writing. As of now, not many scholarly works have been found published on this movement, although news articles, magazine coverage, and other forms of media such as videos have been tracking the movement since it started in March of 2019. As the movement's name implies, the protest started with China's implementation of the Extradition Law. According to a New York Times article:

The bill would allow Hong Kong to detain and transfer people wanted in countries and territories with which it has no formal extradition agreements, including Taiwan and the Chinese mainland... Critics contend that the law would allow virtually anyone in the city to be picked up and detained in mainland China, a country in which judges must follow the orders of the Community Party (Ives, 2019).

In response to what was seen as a clear overreach of power by the mainland government, hundreds of thousands of people in Hong Kong demonstrated against the proposed law. The fear was, and remains, that the law would allow extraditions to mainland China not only of criminals, but also of political activists. This also includes journalists under the assumption that they partake in any action to harm the national security of China, which violates the free press policy of Hong Kong's core value. Although Hong 
Kong's Basic Law is due to expire in 2047, Hong Kong's guaranteed autonomy has weakened drastically as a consequence of the Chinese governments actions, of which the extradition law is only the most recent-and egregious-example. Mike Ives, New York Times journalist, wrote, “[Mainland China's] security apparatus increasingly [encroaches] on Hong Kong-for example, by abducting bookseller and a Chinese-born billionaire" (Ives, 2019). The power dynamic between mainland China and Hong Kong continues to evolve and part of Hong Kong's autonomous identity is lost by each year if not by each day.

\section{Research Analysis}

As mentioned above, during the turnover of Hong Kong in 1997, the island was guaranteed a 50year adaptation period in which established basic democratic freedoms are to be honored by the Chinese state. While China promised to follow through with the time frame set by the turnover treaty, China really did not have the intention to honor this agreement in full. Many warnings of this are found in past scholarly work and in light of recent events they prove to be quite relevant. In this section, the introduction of new laws, and other forms of state power imposed onto Hong Kong by China, are analyzed more in depth.

In the case of the Umbrella Movement, on 31 August 2014, the National People's Congress (NPCSC), a high-leveled governing branch of the CCP, announced that a pseudo-democratic model resembling that of Iran would be introduced for the 2017 Chief Executive election (Ma and Cheng, 2019, p.234). Under Annex I of the Basic Law implies that as early as 2007 Hong Kong could elect the Chief Executive by universal suffrage, yet in 2004, the NPCSC's reinterpretation of the Basic Law denied that privilege. By 2007, the NPCSC consented that the Chief Executive can be elected via universal suffrage in 2017. Ming Sing's comparative politics research explains:

From a mass values approach, support for democracy and trust that the Chinese government in upholding its promises are found to be statistically significant in explaining the massive support 
for the Umbrella Movement. From a performance perspective, the perceived performance of the HKSAR government in handling China-Hong Kong tensions, the perceived economic performance and upward social mobility of Hong Kong, have also shaped the support for the movement (Ma and Cheng, 2019, p.233).

It is because of the lack of trust on the part of Hong Kong's population that the Chinese government to uphold their promise that massive support emerged for the Umbrella Movement, and this ongoing lack of trust has also led to the emergence of the 2019 protests. The 2019 protests started in May and become violent on October $1^{\text {st }}$, when the police started using tear gas on protestors. In December 2019, a survey conducted by the Hong Kong Public Opinion Research Institute showed that $59 \%$ of city residents was in support of the protest while 30\% opposed the protest (Promfret and Jim, 2019). Furthermore, the study indicated that only $17 \%$ expressed support toward seeking independence from China, which means most protestors only want China to return these freedoms, and not necessarily to break away from the Chinese system completely. However, the CCP saw this as a strong threat to their power (BBC News, 2020). By July, the CCP introduced a new national security law to counteract the leading activists of the protest. This national security law criminalizes any act of secession (breaking away from the country), subversion (undermining the power or authority of the central government), terrorism (using violence or intimidation against people), and collusion with foreign or external forces (including Britain and the US) (Tsoi and Wai, 2020).

Hong Kongers saw this new national security law as just as much of a threat as the Extradition Law, if not more. Then the CCP showed immense political presence in Hong Kong on July $8^{\text {th }}, 2020$, when they opened their new national security office in Hong Kong by renovating in a hotel near in the city center (one of the most popular venues for pro-democracy protests). This new headquarters' task is to oversee the Hong Kong government's enforcement of the national security legislation that Beijing imposed on the city. The office holds immense power that extends far beyond what the local Hong Kong 
police force could do, including but not limited to: taking enforcement action beyond existing city laws, allow their agents to take suspects across the border for trials in the CCP controlled courts, and block the Hong Kong authorities to inspect their vehicles (Chow and Kwok, 2020). The CCP claim that purpose of the office is to serve as a gatekeeper for national security, but an important question is why the CCP office opened as soon as the protests started. With an office that holds more power than the local Hong Kong police, the CCP can execute their plans without delays and most importantly to be able to act as an independent institution from the Hong Kong government system.

Even with these constraints, the recent and still ongoing 2019 protests have been more significant than previous protests in a few regards: first, the extent of violence shown by the police; second, the extreme laws enacted to limit social gathering in efforts to stop activists from forming protests; third, the extreme measures taken by the CCP to stop all forms of encouragement for activist activities. An obvious but important physical display of power is the thousands of police officers patrolling the streets of Hong Kong at any hour of the day. Nearly all of the Hong Kong officers are sent to the streets and are given the power to stop protestors at all means including the use of tear gas, water cannon, guns loaded with rubber bullets, and armed trucks. In the first month of the protests the police arrested at least 180 people with several of them hospitalized (Wang et al., 2020). In groups of ten or more the police officers had an overpowering stance over mostly unarmed protestors. The police claimed that they had deployed tear gas to disperse protestors who blocked traffic and threw umbrellas, water bottles and other objects at officers. However, according to many videos on social media the police officers chased down many protestors and fired pepper balls or tear gas at close range. This may be more violence than necessary to simply clear the streets of protestors, it is a reminder for Hong Kongers that the government's decisions are final. On the other hand, some protestors acted more violently than before after the government showed no mercy. A Hong Kong theater artist, Michelle Chung said, “I wouldn't use optimistic but I would say that if we do not insist, we will not see hope. It's 
because we insist, that hope will remain out there" (Wang et al., 2020). Hope is indeed important in any protest, but Beijing intends to diminish any hope. For example, police offices are allowed to use force to break up any gathering on the street, search anyone they see on the street without reason, and arrest anyone who seems to be pro-democracy including holding up banners, signs, umbrellas, or wearing any logos that is associated with the protest. These government actions spread a sense of fear to anyone who supports the protest and as a result a non-visual grip is taken place over each Hong Konger's behavior toward the protest.

Furthermore, hope is created through encouragement of fellow peers and other forms of support, but this hope can easily be shatter if the support foundation is destroyed. This is precisely what the CCP hope to do. In 2007, Dutch artist Florentijn Hofman set afloat a massive, 12-metre rubber duck in Victoria Harbour as part of a planned world tour. By 2013, the yellow rubber duck arrived in Hong Kong's harbor. This symbol quickly became Hong Kong's business and spirit of 'can do' (Sito, 2018). Yellow duck merchant stores started to pop-up as it became more popular. In 2019 the duck became a symbol for the 2019 Protest as the yellow umbrella had been for the Umbrella Movement. Journalist Leonid Bershidsky noted that the yellow rubber duck is a potent protest symbol that had been used all over the world for diverse reasons such as the 2016 government corruption protest in Brazil (2017). More recently in 2020, Thailand protestors used rubber yellow ducks as a symbol of the antigovernment protest. Beijing have recognized the effects of a symbolic figure to protestors, hence making it a priority to stop the spread of this yellow duck as efficiently as possible. Herbert Chow, owner of clothing brand Chickeeduck, had been struggling to get his designs made in mainland China since the protest started and his duck print products were seized by mainland authorities for 'advocating violence' (SCMP, 2021). For example, Chow's design on a bag shows on one side five yellow ducks swimming and on the other a duck holds a flag while standing on a rock. The CCP says this design represents 'five demands, not one less,' which was a slogan used in the 2019 Hong Kong anti-government protest. The 
five demands being: full withdrawal of the extradition bill, a commission of inquiry into alleged police brutality, retracting the classification of protesters as "rioters," amnesty for arrested protesters, and lastly, dual universal suffrage for both the Legislative Council and the Chief Executive (Tsui-kai, 2019). By removing the yellow duck designs from the clothing market Beijing can manage the spread of word for the protest as well as convey the message that Hong Kong's business and spirit of 'can do' is something the CCP can easily be taken away, or in other words Hong Kong should keep to their boundaries.

Any kind of support shown toward the protest would be an obstacle to Beijing's plan. This even includes Apply Daily, one of the most popular and biggest pro-democracy newspaper in Hong Kong (Marsh, 2021). It took only a year for the new National Security Law to end Apply Daily's free press journey that started in 1995. Chief Executive of Hong Kong, Carrie Lam, promised in 2019 when the National Security Law was introduced that press freedoms would be protected, but it seems that promise did not last. Apple Daily's founder, Jimmy Lai, was jailed for attending a pro-democracy rally and charged with colluding with foreign forces to endanger national security. Since Lai's arrest in December of 2020, four more top editors of the newspaper and executives had been charged the same crime, which was using articles to voice for foreign governments to sanction Hong Kong. Since these arrests hundreds of police officers raided the publication office twice while seizing computers and materials. Some journalists chose to quit their positions as their work had become too dangerous to continue. To completely dismantle the daily functions of Apply Daily, Hong Kong authorities had frozen all of the company's bank accounts which forced the company to announce its final end. This is important to note because in the Umbrella Movement of 2014 Lai's Apple Daily became a symbol of the opposition to the CCP's plan of how Hong Kong's leader would be selected (Marsh, 2021). During the 2019 Protest, Apple Daily's front page often urged readers to attend planned protests. The company even printed anti-government posters for these protests to carry on the streets. It seems that the CCP grew impatient with political positions that diverge from those of their own. The freedoms of Hong Kong 
are quickly diminishing as the protest in Hong Kong continues. It is precisely through fear of getting in trouble with the authorities that the CCP is able to greatly diminish any hope that remains in the possibility of pro-democracy legislation. Even with the support of the public in the selling out 500,000 newspaper copies, Apple Daily can not win a war against an all controlling government. This is a massive indicator of how shallow Hong Kong's basic freedoms had gotten since its return to China. While Carrie Lam tried to dismiss the fear of losing these basic freedoms by suggesting that these police probe into Apply Daily were "unrelated to normal journalist work" (Marsh, 2021). However, there is no denying the fact that forcing a pro-democracy newspaper to close and threating journalists with time in jail is part of a governing process to create fear and minimize the freedom of press. The Basic Law which guaranteed freedom of expression and the media seems to be ineffectual against the new national security law that had set increasingly narrow parameters for journalists to work with. President of NGO Freedom House, Michael J. Abramowitz, said, "Treating independent, fact-based journalism as a threat to national security is an unacceptable attack on press freedom and comes amid a wider crack down of freedom of expression and freedom of assembly in Hong Kong" (Marsh, 2021). This is a sign from the CCP that anyone who has the desire to support present or future protests will be accounted to go against the new National Security Law or in other words against the CCP.

Through this analysis of Beijing's increasing amendments to Hong Kong's laws it can be concluded that Beijing had little intention of allowing Hong Kong to stay democratic regardless of the treaty signed with Britain. As Lee Jonghyuk, an assistant professor at Singapore's Nanyang Technological University said, "There will be no reversion [for Hong Kong]. This is quite certain. Universal suffrage is a mere obstacle to the stability of the Community Party's regime" (IIlmer, 2021). The new power dynamic status is much leaned toward the advantage of the Communist Party without doubt, yet Beijing intends to not only 'trample' on Hong Kong (as many journalists describe the situation), but to make its political presence more known in Hong Kong than ever before. 


\section{Hong Kong's social impact}

While the streets of Hong Kong seem to be back to normal in 2021, the protest is far from being over. The streets still have graffiti that are uncovered and some buildings are still under renovation. More importantly, the economic and social impacts of the protests are visible everywhere in Hong Kong. The island has reached the widest political divide in its history. For example, never have local businesses in the global financial hub been so politically divided. Mobile phone application platforms have popped up showing maps of businesses that are believed to be supporting the protests as well as those that are not. Restaurants that support the Hong Kong movement have yellow stickers on their doors while those supporting the Chinese government have blue stickers. Scanning the stickers QR code shows a Google Maps page revealing assumed yellow and blue around the city (CNBC, 2020). Activists also classify an area that is marked black on media platforms as 'thrashing' (to destroy the entirety of the property) while red indicates spray-painting the area (Wai, 2019). Although these more extreme actions are no longer as common on the streets of Hong Kong, this social divide forces Hong Kongers to choose a side in the ongoing political dispute over the future of the island. For example, some customers choose to support specific restaurants over others because they want to support the protestors (CNBC, 2020). Some Hong Kongers feel that a pro-democracy restaurant gives them a safe environment to express themselves as well as gather with like-minded people. An undeniable fact is that Hong Kong is becoming more divided as the protests go on. It is unknown how long this kind of business model will last in the city, but it may lead to greater economic problems later. For example, businesses can be threatened to close down by the government, vandalized by the public, or even boycotted due to these political differences. In early October of 2019, Starbucks stores in Hong Kong were vandalized and boycotted by protestors. While Starbucks is a U.S. brand, the local company, Maxim's Caterers, operate the franchise. Annie Wu, daughter of the Maxim Group's founder, had defended the Hong Kong police and criticized the activists as 'radical protesters' (Wai, 2019). Her statements were enough for Hong Kongers to 
boycott Starbucks completely. Maxim's Caterers had a spokesperson explain that Annie Wu's words does not reflect the company as she is not associated with the company, however the damage has been done and many customers have not returned. More recently a Hong Kong drinks company, Vitasoy, has been boycotted by China's Mainlanders. Vitasoy expressed condolences to the family of a deceased employee who died after stabbing a Hong Kong police officer before turning the knife on himself (Hui, 2021). On social media, Hong Kongers praised Vitasoy for its condolence, however, Mainlanders saw it as an expression of supporting the assailant. As $71 \%$ of Vitasoy's revenue in 2020 comes from mainland China, the company quickly posted on social media the next day saying Vitasoy supports the Hong Kong national security police's investigation on the attack and that they retain the right to take legal action against the employee who sent the unauthorized "extremely inappropriate" memo on social media. Some Chinese actors such as Gong Jun and Ren Jialun announced that they would cease to cooperate with Vitasoy in the future. This led Vitasoy's stock exchange in Hong Kong to fall over $10 \%$ on July 5 , 2021. These kinds of boycotts seem to become more and more common in Hong Kong. This protest is changing the financial hub for the worse because more businesses will be targeted in the future. It seems that no matter which side a business chooses to support the public's reaction is negative. This negativity can destroy a well-established business regardless of the brand's origin or its business category.

Disney's live-action remake of Mulan released in Hong Kong in September, but the film faced many criticisms in Hong Kong. First, Yifei Liu who played as Mulan in the film reshared a post from People's Daily, a state-backed newspaper. The reshared post read: "I support the Hong Kong police. You can all attack me now", which is a rallying cry for the Chinese government and its supporters Liu shared the above post on Weibo, a Chinese social media platform, and added in Chinese, "I also support the Hong Kong police" (Chow, 2020). This generated 81,000 likes but it also received backlash from those who supported the protest. For example, Joshua Wong, a well-respected activist leader in the 2019 
Protest, posted on Twitter saying, "This film is released today. But because Disney kowtows to Beijing, and because Liu Yifei openly and proudly endorses police brutality in Hong Kong, I urge everyone who believe in human right to \#BoycottMulan" (Chow, 2020). Supporters of the protest intensified their criticism even more after seeing the film's credits giving thanks to several government entities in Xinjaing including the Turpan Municipal Bureau of Public Security. In November 2019, leaked documents of the CCP revealed that the Turpan Municipal Bureau of Public Security had at least one million Muslims have been detained at detention camps for Muslim Uighurs and other ethnic minorities. The prisoners were subjected to physical control and mental intimidation, which human rights advocates claim is an abuse to human rights (Campbell, 2010). While Disney's representative and Liu's publicist did not immediately respond to requests for comment, it is important note how sensitive the 2019 Protest has become since its start. Both the supporters of the protest and the supporters of the government are willing to go to extreme lengths to find fault in the other. The political divide in Hong Kong's society becomes stronger and more visible as the protest drags on.

Even well-established Hong Kong celebrities, like global martial arts star Jackie Chan, have been criticized by netizens. In August 2019, Chan reshared a post on Weibo, a Chinese social media platform, by the mainland state media, CCTV, and the posted content is a Chinese national flag with the hashtag of "Five starred red flag has 1.4 billion flag guards" (Atkin, 2019). Although Chan is not the only celebrity of Hong Kong to support Beijing, he was among the first to criticize the protest openly. Chan even tells the Chinese state media in an interview after the reshared post incident that, "Safety, stability, and peace are just like fresh air, you never know how precious it is until you lose it" (Atkin, 2019). Hong Kongers were outraged by these comments and marked him as a traitor of Hong Kong. Some prodemocracy activists even suggest Hong Kong people should boycott all his artist creations all together, including his albums and movies. It is uncertain if Jackie Chan's reputation will revive in Hong Kong but his career has certainly been impacted. Another well-known Cantonese celebrity is Liza Wang, who 
actually left Shanghai as a young woman to seek out an acting career in Hong Kong. In an interview by South China Morning Post, Wang admitted that she first became a member of the National People's Congress in 1988 and to this day it's been thirty years. She was part of the National People's Congress for ten years and twenty years as part of the Chinese People's Political Consultative Conference. Wang says she goes back to the mainland on occasion to perform, but anything outside of Hong Kong is considered a bonus market. She states:

I feel we can't keep thinking we are still as we were decades or say twenty years ago. You need to really understand that the speed of mainland China's rise is very fast. If you just sit and wait, then what are you waiting for? And when it comes to those who are not willing to take a look at the mainland, which is a huge amount of Hong Kong people... One needs to learn from others in order to strengthen oneself and connect with the world... I feel the most important thing to admit is that you are Chinese. You don't need to emphasize it all the time. I don't know why it seems like you have to choose to be either a Chinese or a Hong Konger. I think we are all Chinese people. First, you need to say who you are then you can accept everything about the mainland. We're actually part of it, right? (SCMP, 2018).

Both interviews show that older celebrities of Hong Kong believe Hong Kongers are indeed Chinese. According to a survey by the Chinese University of Hong Kong the demographics of the protesters are as follows: 19 years or younger is $11.5 \%, 20-29$ years old is $46.3 \%, 30-39$ years old is $18.2 \%, 40-49$ years old is $8.9 \%$, and 50 years and older is $14.2 \%$. The protesters education level is $75.2 \%$ with college education, $23.5 \%$ with secondary education, and only $1.1 \%$ with primary education (Buchholz, 2019). This could mean that older generations of Hong Kongers feel more connected with their Chinese roots than that of being a British subject. This analysis shows that a vivid social divide between the different generations of Hong Kong people had been established in Hong Kong. This kind of divide can affect Kong Kong's future 
greatly. For example, Beijing must have a firm holding over Hong Kong's every move before more kinship in Hong Kong refuse to acknowledge their Chinese identity.

Also worth analyzing is that the above data shows the political attitudes of Hong Kongers has been changing for years. Joseph Y.S. Cheng, professor of political science at the City University of Hong Kong, found that "While [Hong Kong people] perceived democracy as an important means to guarantee their freedoms, their lifestyles, and their living standards, they also consider that their own individual efforts are more significant - more liable to improve their lives. Such attitudes and orientations continue to define political participation in Hong Kong in the mid-1990s" (Cohen and Zhao, 1997, p.183). After every protest in Hong Kong's history of democracy, it seems more supporters show on the streets and the younger the age group gets. This is a correlation worth noting because if the problem is that younger generations do not feel "Chinese" enough, in which they feel closer to being a British subject, then what Beijing may consider doing is reconnecting these younger generations to Chinese nationalism. Regardless of whether the CCP decide to reintroduce Chinese nationalism to Hong Kong youth or not, Hong Kong's social impact from the protest will certainly last beyond the protest period.

Unlike Liu, Chan and Wong, some entertainers did openly support Hong Kong's protests. For example, Denise Ho, a Cantopop singer, voiced her support for the pro-democracy movement of 2019. Beijing decided to blacklist Denise Ho from the mainland Chinese market. Anthony Wong, a Hong Kong actor, openly supported the Umbrella Movement in 2014, but by going against the government he lost over half of his annual income from mainland China. Anthony Wong says in an interview with the New York Times, "I think they are trying to ban us because they're afraid of different views" (Chow, 2020). It is a norm for Chinese entertainers to support the government or not say anything at all as to avoid negative career implications. This explains how the CCP utilized fear to control Hong Kong much earlier than the current pro-democracy protest. The longer that Hong Kong protesters continue these protests the harder it becomes to rally more supporters because of the legitimate fear of CCP reprisals. Hong 
Kong is changing as the CCP continues to gain control over Hong Kong's government, economy, and society, and these changes have many grave implications for the future of democracy and autonomy in Hong Kong. Hong Kong is known to be a global financial hub of opportunity, but the unsteady political conditions have changed that perception. Besides Vitasoy many businesses have fallen victim to the political wrath of mainlanders including the National Basketball Association (NBA), luxury brands Givenchy and Versace, fashion retailer H\&M, and gaming company Blizzard Entertainment, while supporters of the protest boycotted Disney's Mulan and Starbucks. It is certain that if this political dispute continues it will harm Hong Kong's future economy as it becomes a less attractive business location to investors.

\section{Hong Kong's stock exchange and mainland China's special economic zones (SEZ)}

When Hong Kong was returned to China in 1997, Philip Bowring, a columnist for the International Herald Tribune and consultant to Kleinwort Benson Securities Asia, warned, "Hong Kong faces multiple challenges. Its biggest challenge may be to retain its own openness and accessibility. For example, its freedom of the press and lack of politically driven constraints on social behavior have given it an advantage over Singapore" (Cohen and Zhao, 1997). He argues that the huge foreign portfolio presence in Hong Kong's stock market is a major benefit and that the market ha grown very large relative to the size of the economy in which the market capitalization is around 400 billion U.S. dollars while the gross domestic product (GDP) is around 150 billion U.S. dollars in 1997. Frank Ching, senior editor for the Far Eastern Economic Review and one of the founders of The Wall Street Journal's bureau in Beijing, says, "The territory also benefits from a large number of entrepreneurial businessmen who are constantly on the look out for new opportunities. It boasts a level playing field for business, as well as an efficient, honest and apolitical civil service and an independent judiciary" (Ching, 1996). If the foreigners who pumped up the Hong Kong economy lose faith in their market, then Hong Kong could be in serious economic trouble. While Hong Kong managed to handle the handover in 1997, history has 
repeated itself in that Hong Kong faces the challenge of retaining its openness and accessibility once again. This time however Hong Kong shows signs of losing these freedoms, as China ascends as a world superpower.

To understand the financial establishments of Hong Kong, it is necessary to briefly review the history of Hong Kong's stock exchange history. In 1891 the Association of Stockbrokers in Hong Kong (named The Hong Kong Stock Exchange in 1914) was form, the first formal stock exchange platform in Hong Kong. The second stock exchange was incorporated in 1921. By 1947 the two stock exchange platforms above merged to form a joint exchange under the name of "The Hong Kong Stock Exchange Ltd" (HKEX, 2021). Later, three more stock exchanges opened for business: The Far East Exchange Ltd opened in 1969, The Kam Ngan Stock Exchange Ltd opened in 1971, and The Kowloon Stock Exchange Ltd opened in 1972. By 1980, the Stock Exchange of Hong Kong Ltd was incorporated. Although the previous four stock platforms fared well for a while under new stock trading rules, they all closed business on March 27th, 1986 and leaving only the Stock Exchange of Hong Kong Ltd or as known as the Hong Kong Stock Exchange (HKEX). After the 1987 market crash in Hong Kong, it led to the reform of the Hong Kong securities industry, in which the Securities and Futures Commission (SFC) was formally established in 1989, the same years as HKEX's formation of the Hong Kong Securities Clearing Company Ltd. It wasn't until 1999 that growth companies that do not fulfill the requirements of profitability or track record for the main board of exchange could list in the new open platform of the Growth Enterprise Market (GEM). With new regulations in place and the market infrastructure improved (i.e. the Central Clearing and Settlement System (CCASS) and the Automatic Order Matching and Execution System (AMS)), Hong Kong thrived as a global financial hub. The HKEX and GEM are the two boards of investment in Hong Kong that will be analyzed to assess the change of Hong Kong's financial growth.

The gross domestic product (GDP) of Hong Kong from 2006 to 2019 grew approximately 91\%. In 2006 Hong Kong's GDP was 1503.35 billion Hong Kong dollars (HKD) or 193.36 billion USD and each year 
the GDP increased (with the exception of 2009 due to the Global Recession). The most recent data shows that Hong Kong's 2019 GDP was 2865.68 billion HKD or 368.68 billion USD (Textor, 2021). This indicates that Hong Kong's overall economy is doing well and is still considered a notable global financial hub despite the protest starting in mid-2019. However, the GDP is a superficial number in that the economic information is too broad. The reason is that the financial services industry accounted for over a tenth of Hong Kong's GDP as early as 2000 at $12.8 \%$ (Hong Kong Consensus and Statistics Department, 2021). Since 2000, financial services had been increasing steadily and in 2019 financial services accounted for $21.2 \%$ of Hong Kong's GDP (Textor, 2021). This means a fifth of Hong Kong's GDP is related to the stock market in one way or another. The CCP and mainland businesses knew that foreigners trusted Hong Kong as a global financial hub, hence it was a great way to utilize the HKEX and GEM to gather foreign investments. Tsingtao Brewery Co Ltd became the first mainland incorporated enterprise to obtain a primary listing in Hong Kong as early as 1993 (HKEX, 2021). The number of mainland enterprises only increased as the number of yuan-dominated investment products (yuan being the currency of mainland China) in Hong Kong went from 222 in 2016 to 287 in 2020 (Slotta, 2021). The number of listed companies in Greater China in 2020 by stock exchange is: HKEX at 2710, HK GEM at 368, Shanghai at 1843, Shenzhen at 2390, and Taiwan at 948 (Slotta, 2021). This means HKEX is the most popular stock exchange platform for Chinese companies to gather investor funding (especially foreign funding). More importantly it indicates that Hong Kong still is an important global financial hub for Beijing and all its mainland businesses. Mainland companies are not just dominating the financial hub but the leading companies at the HKEX in 2020 based on market capitalization are also mostly dominated by mainland companies: first as Tencent Holding Ltd. (5409.7 HKD), second as Alibaba Group Holding Ltd. (5034.65 HKD), third as Meituan (1733.42 HKD), fourth as China Construction Bank Corporation (1416.06 HKD) (Slotta, 2021). These four companies' capitalization added together is about 2.5 times or more than double the capitalization of the rest of the top ten companies combined (of 
which most of these are also mainland companies). Mainland China stocks had been taking over Hong Kong slowly over the years and it has certainly dominated how Hong Kong's economy functions now.

Another important analysis is that there has been a downside for mainland China in terms of the HKEX market turnover of the securities (the higher the share turnover, the more liquid company shares are) as it has been unpredictable. In other words, how often people buy and sell the stocks at the HKEX has little correlation from previous years. For example, the turnover rate in 2013 is $15.26 \%$, in 2014 it's 17.16, in 2015 it's 26.09, in 2016 it's 16.4, in 2017 it's 21.71, in 2018 it's 26.42\%, in 2019 it's 21.44\%, and in 2020 it's 32.11\% (Slotta, 2021). Note that each time a protest happens the stock market of Hong Kong is greatly affected before it goes back up. The Umbrella Movement happened in 2014 and 2014's turnover rate showed minimal increase (1.9\%) from the turnover rate of 2013. The Mong Kok Protest in 2016 caused the market turnover rate from 2015 's $26.09 \%$ to just $16.4 \%$ at the end of 2016 . When the 2019 protest started the market turnover fell from $26.42 \%$ in 2018 to $21.44 \%$ at the end of 2019 . While 2020 shows a market turnover rate of $32.11 \%$, the highest it has been in years, it is still clear that protests in Hong Kong is strongly related to how the market performs, which means in order for the largest mainland companies to continue to be successful in gaining foreign investment the CCP must stabilize Hong Kong's political situation. Of course, the CCP realizes that the dependent relation with Hong Kong's stock market must end or gain full control of the operations of Hong Kong.

The CCP had been innovative in alleviating the above issue for some time, even before the return of Hong Kong to China. First, Beijing invested in creating special economic zones (SEZs). Willem van Kemenade, freelance journalist for the major Dutch newspaper NRC Handelsblad, said in his book, China, Hong Kong, Taiwan, Inc.:

To further China's dual goals of reintegration with Taiwan and Hong Kong and acceleration of outward economic development, four special economic zones were established in the 
southeastern coastal belt near Hong Kong and Taiwan... If they lived up to their high expectations, the SEZs were destined to become showplaces of high technology, modern management, and efficiency. Production was meant to serve the foreign market, with the aim of raking in foreign currency, in its turn to pay for the import of high technology. This experience would then seep out to the hinterland, leading to the proliferation of advanced industrial estates (van Kemenade, 1998).

The first four SEZs established in 1980 were Shenzhen, Zhuhai, Shantou, and Xiamen. These zones were exempt from administrative interference from local authorities, received large amounts of government funding for infrastructure projects, and were allowed to extend special privileges to foreign investors such as tax exemptions of up to five years and the permanent lowering of taxes depending on the type of technology. Tax rates outside the zones was $20 \%$ compared to $15 \%$ for businesses inside. This attracted a lot of attention from investors, especially Shenzhen. Shenzhen's GDP in 2019 was 2692.7 billion RMB (416.51 billion USD), just below Shanghai and Beijing. The annual growth rate of Shenzhen's GDP has been above $0 \%$ for the past decade with the highest in 2010 at $12.3 \%$ growth. Even before these results, in 1984, the SEZ economic model was already deemed successful and could be expanded further to fourteen coastal port cities by the CCP. By 1992, sixty SEZs have been set in China and by 2005 , there were 210 national development zones along with 1,346 provincial development zones (Rodrigue, 2021). Since China's geography of production is strongly coordinated with its proximity to coastal areas and its capabilities of utilizing ports and airport terminals to access global markets, the importance of Hong Kong to the CCP has dramatically devalued over time. Van Kemenade also said in his book, "Hong Kong, which had been China's most important source of foreign currency since the 1950s, now became the base par excellence from which to make the great leap toward the fabulous Chinese market of which the West had dreamed for more than a hundred years" (van Kemenade, 1998, p.61). China has learned from Hong Kong and Taiwan's success and through trial and error have indeed made a 
great leap toward the fabulous Chinese market, a very important milestone in becoming an acknowledge global superpower.

Secondly, to alleviate the Hong Kong dependency, China opened stock market platforms of their own in the mainland. Yiu-wai Chu, director of the Hong Kong Studies Program and professor of Modern Languages and Cultures at the University of Hong Kong, said, "One of the major problems is that both transitional corporation and Hong Kong itself have agreed that it is essential to keep Hong Kong as it is in term of its social, legal, and capitalist systems after 1997, and Mainland China did not dispute this notion. In reality, Hong Kong will not have any niche over Mainland cities in the long run if they continue to open up their markets" (Chu, 2013, p.164). As the mainland continues to open, mainland Chinese companies start relying on the Hong Kong market less, which means Hong Kong becomes less of an unpredictable liability to the CCP's plans of future development. On December $1^{\text {st }}, 1990$, Shenzhen opened its Shenzhen Stock Exchange (SZSE) and Shanghai's Shanghai Stock Exchange reopened on December $19^{\text {th }}$ of the same year. In 2019 the GDP of Hong Kong was 2865.68 billion HKD or 368.68 billion USD, while Shanghai's GDP was 3815.5 billion RBM or 590.44 billion USD and Shenzhen's GDP was 2692.7 billion RBM or 416.69 billion USD (Textor, 2020; Textor, 2021). Willem van Kemenade in 1998 said, "Now, in the 1990s, there is little doubt that Shanghai will eventually overtake Hong Kong in terms of sheer economic power, but it is difficult to imagine it ever acquiring the sophistication, the symbiosis of East and West, the civil order and legal security, and the freedom of information that Hong Kong now enjoys" (van Kemenade, 1998, p.57). It is evident that China's mainland economic development is surpassing Hong Kong and that is just two of China's many special economic zones. While Shengzhen and Shanghai are the only ones to have a well-established stock exchange platforms so far, these two cities show exceptional economic success. Through the example of these two cities other cities in the mainland can potentially create their own stock exchange platforms as well. Although the chances may not be high in the next decade, but this possibility cannot be dismissed. With SEZs helping the mainland 
develop, Hong Kong is becoming less significant to the CCP as their economic importance has deteriorated over time. Hong Kong's economic development speed in comparison to China's new Special Economic Zones (SEZs) is much slower at this point. Indeed, it is difficult to imagine SEZs ever "acquiring the sophistication, the symbiosis of East and West, the civil order and legal security, and the freedom of information that Hong Kong now enjoys" as van Kemenade says. However, without Hong Kong's current freedoms will Hong Kong be any different from these SEZs? The answer remains to be answered in the future, but as Hong Kong's freedoms are stripped the aspects that make Hong Kong a special global financial hub also disappears over time.

\section{Conclusion}

China never intended to honor the agreement of democracy with Hong Kong until 2047. The politically troublesome Hong Kong is no longer worth the CCP's patience. In this thesis I have analyzed why China had minimal intentions of allowing Hong Kong to remain autonomous and democratic following the 1997 turn over from Britain. With the current economic power dynamic between Hong Kong and mainland China, China is unlikely to return the freedoms taken from Hong Kong such as the freedom of the press, speech, and assembly. Since the 1997 turnover, many scholarly articles and books had advised Hong Kong people of their dire position if China continues to open up the mainland for foreign businesses. These shifts threaten the very foundation of Hong Kong's economic advantage over the mainland. Scholars such as Yiu-Wai Chu, Joseph Y.S. Cheng, William van Kemenade, Ming Sing, and Yongshun Cai, all provide convincing evidence as to why political freedoms in Hong Kong are steadily eroding in the face of an organized and determine CCP and in the context of China's economic rise over the past several decades. Through analysis of how China increased its political presence in Hong Kong, added new laws/ amendments to Hong Kong's government, and diminished the freedoms of the Hong Kong people, I found that China is slowly changing the Hong Kong democratic governing system from the inside out. Instead of giving Hong Kongers voting rights in new laws and in choosing their governor, it is 
simpler and more efficient for the CCP to directly control the Hong Kong government, which includes the Hong Kong police force.

In addition, using comparisons of Hong Kong's recent GDP and stock market platforms with that of mainland China's, I found that Hong Kong is no longer as powerful nor as important to the Chinese government as it was at the time of the handover. Hong Kong waited too long to attempt to break free from China's communist rule. It is likely that, moving forward, Hong Kong's title as a global financial hub will not give the island any advantage over the mainland cities, nor will it receive any favoritism from the CCP. In the meantime, while the streets of Hong Kong have been cleaned up and certain areas are renovated to what it looked like before the violent protests, the economic and social impact is still visible. Hong Kong has been divided into pro-democracy and pro-government. A government system is only as strong as the people's unity and trust. If the people of Hong Kong are not united, then it is more likely that Hong Kong's political system will further deteriorate and succumb to the coordinated tactics of the Chinese Communist Party to solidify mainland control of the island. For Hong Kong to reclaim some of its lost freedoms, the people must realize their dire position in power and reframe from pushing the CCP too far politically until Hong Kong becomes more economically important to Beijing again. Further study and analysis of Hong Kong's struggling democratic institutions are required, such as what freedoms Hong Kong are still allowed to enjoy. Perhaps studies of Hong Kong's culture and other aspects that make the island unique will bring light to how Hong Kong can utilize these advantages to regain or even out the sense of important lost through economic means. It must not be ignored that there is a chance that the democracy of Hong Kong will be completely dismantled by the CCP. Moreover, foreign nations in time must acknowledge China's undeniable status as a global superpower. 


\section{References}

Atkin, N. (2019, August 16). Jackie Chan's Hong Kong protests spark social media anger as martial arts star calls for peace. South China Morning Post. https://www.scmp.com/sport/martial-arts/kungfu/article/3022936/jackie-chans-comments-hong-kong-protests-spark-social.

Bajpai, P. (2021, June 2). China will continue to dominate world production. Investopedia.

https://www.investopedia.com/articles/investing/102214/why-china-worldsfactory.asp\#: :text=In\%20addition\%20to\%20its\%20low, duties\%2C\%20and\%20competitive\%20c urrency\%20practices

BBC News. (2020, October 02). China National Day: Hong Kong peace 'is an illusion'. Retrieved October 23, 2020, from https://www.bbc.com/news/world-asia-china-54382112

BBC News. (2019, June 24). Hong Kong profile - Timeline. BBC News. https://www.bbc.com/news/world-asia-pacific-16526765

BBC News. (2019, February 1). Taiwan profile - Timeline. BBC News. https://www.bbc.com/news/world-asia-16178545.

Bershidsky, L. (2017, March 29). The yellow rubber duck is a potent protest symbol. Bloomberg Quint. https://www.bloombergquint.com/opinion/the-yellow-rubber-duck-is-a-potent-protest-symbol.

Bierling, J., \& Murray, G. (1995). The 'Emerging Powers': China, Singapore, Hong Kong and Taiwan. Current Sociology, 43(1), 65-96. https://doi.org/10.1177/001139295043001004 Bradsher, K. (2005, March 20). In Hong Kong, China Prefers Power to Law. New York Times, 
WK4. https://link.gale.com/apps/doc/A130541450/GPS?u=s1185784\&sid=GPS\&xid=b1b9e4cb

Bradsher, K., \& Wang, V. (2021, January 16). In Hong Kong, a new party calls for stability (and raises suspicions). The New York Times. https://www.nytimes.com/2021/01/16/world/asia/hongkong-politics-bauhinia.html.

Britannica. (2020). Government and society. Retrieved November 29, 2020, from https://www.britannica.com/place/Hong-Kong/Government-and-society

Buchholz, K. (2019, September 3). Infographic: Who are the Hong Kong Protesters? Statista Infographics. https://www.statista.com/chart/19222/demographic-profile-of-hong-kong-protesters/.

Cable News Network (CNN). (2019, August 1). Hong Kong protests: updates and latest on city's political unrest. CNN. https://www.cnn.com/specials/asia/hong-kong-protests-intl-hnk.

Cable News Network (CNN) (Producer). (2014). People power. [Video/DVD] Cable News Network (CNN). Retrieved from https://video-alexanderstreet-com.proxy.lib.pdx.edu/watch/people-power-2

Campbell, C. (2019, November 25). Leaked files claim to reveal details of China's Muslim Camps. Time. https://time.com/5738401/xinjiang-uighur-muslim-camps-china-cables/

Census and Statistics Department Hong Kong. (2021, May 14). Gross domestic product (GDP) share of the financial services industry of Hong Kong from 2009 to 2019 [Graph]. In Statista. Retrieved August 04, 2021, from https://www-statista-com.proxy.lib.pdx.edu/statistics/621928/hongkong-financial-services-industry-gdp-share/

Census and Statistics Department Hong Kong . (2021, May 14). Table 188: Value added and employment 
in respect of the Four Key Industries. Census and Statistics Department. https://www-censtatdgov-hk.proxy.lib.pdx.edu/en/web_table.html?id=188

Chan, M. K., \& Young, John D. (1994). Precarious balance: Hong Kong between China and Britain, 1842-1992. M.E. Sharpe.

Cheng, Y. S. (2005). The July 1 protest rally: interpreting a historic event. City University of Hong Kong Press.

Cheung, H., \& Hughes, R. (2020, May 21). Why are there protests in Hong KONG? All the context you need. BBC News. https://www.bbc.com/news/world-asia-china-48607723.

Cheung, T. (2020, October 02). Beijing urges swift UK response to Hong Kong protest outside London embassy. Retrieved October 23, 2020, from https://www.scmp.com/news/hongkong/politics/article/3103934/beijing-urges-swift-british-response-burning-chinese-flag

Ching, F. (1996). Hong Kong and China: "one country, two systems"? New York, NY: Foreign Policy Assn.

Chiu, T. Y. (2020). Everyday mixed status: spillover effects of state power in Mainland China-Hong Kong cross-border families. Gender, Place \& Culture, 27(5), 643-659.

Chow, A. R. (2020, March 2). Why fans called for mulan boycott amid the film's release. Time. https://time.com/5653973/mulan-boycott-liu-yifei/

Chow, Y., \& Kwok, D. (2020, July 8). Beijing opens new national security headquarters in Hong Kong hotel. Global News. https://globalnews.ca/news/7151084/hong-kong-hotel-beijing-nationalsecurity/. 
Chu, Y. (2013). Lost in transition : Hong Kong culture in the age of China. State University of New York Press.

CNBC. (2020). What Hong Kong's protests mean for business | Cnbc Reports. CNBC. https://www.youtube.com/watch?v=JY1y4xaK8m4.

Cohen, W. I., \& Zhao, Li. (1997). Hong Kong under Chinese rule : the economic and political implications of reversion. Cambridge University Press.

Davidson, H. (2021, January 6). Hong Kong arrests: Who are the pro-democracy activists being targeted? The Guardian. https://www.theguardian.com/world/2021/jan/06/hong-kong-arrests-who-arethe-pro-democracy-activists-being-targeted.

Davis, R., \& Chow, V. (2019, August 15). As Hong Kong PROTESTS Continue, stars get caught up in the vitriol. Variety. https://variety.com/2019/film/news/hong-kong-china-protests-jackie-chandenise-ho-tony-leung-ka-fai-1203302040/.

Dragon strike; China's power. (2020, May 30). The Economist, 8(US). https://link.gale.com/apps/doc/A625090092/GPS?u=s1185784\&sid=GPS\&xid=c968b670

DW News. (2021, May 27). Hong Kong passes new electoral LAW reducing voting rights: Dw: 27.05.2021. DW.COM. https://www.dw.com/en/hong-kong-passes-new-electoral-law-reducing-votingrights/a-57683043.

Elliott, M., \& Elliott, D. (1997, May 19). Why the world watches: 
how China treats Hong Kong will reveal its true face. Newsweek, 129(20), 30+. https://link.gale.com/apps/doc/A19398108/PPCM?u=s1185784\&sid=bookmarkPPCM\&xid=18a0bcc5

Fan, W., \& Lyons, J. (2020, October 7). China snatched the 'hong Kong 12' off a Speedboat, Giving protest Movement new life. The Wall Street Journal. https://www.wsj.com/articles/chinasnatched-the-hong-kong-12-off-a-speedboat-giving-protest-movement-new-life-11602063213.

Films Media Group. (2010). China: The rebirth of an empire. Films On Demand. https://fod.infobase.com/PortalPlaylists.aspx?wID=102733\&xtid=47575

Gunia, A. (2019, June 20). A brief history of protest in Post-handover Hong Kong. Time. https://time.com/5606212/hong-kong-history-mass-demonstrations-protest/.

GovHK. (2020, August 25). GovHK: Government Structure. Retrieved November 29, 2020, from https://www.gov.hk/en/about/govdirectory/govstructure.htm History.com Editors. (2010, February 9). Britain agrees to return Hong Kong to China. History.com. https://www.history.com/this-day-in-history/britain-agrees-to-return-hong-kong-to-china. HKEx. (2004). Hong Kong Stock Market Historical Events. HKEx Fact Book 2004. https://www.hkex.com.hk/-/media/hkex-market/news/news-release/2006/060116news/30 HKExnews. (2021, March 10). Leading companies at the Hong Kong Exchange in Hong Kong in 2020, based on market capitalization (in billion Hong Kong dollars) [Graph]. In Statista. Retrieved August 04, 2021, from https://www-statista-com.proxy.lib.pdx.edu/statistics/1228889/hongkong-leading-companies-in-market-cap-at-hkex/ 
HKExnews. (2020, December 17). Market turnover of the securities market at the Hong Kong Stock Exchange from 2013 to 2020 (in trillion Hong Kong dollars) [Graph]. In Statista. Retrieved August 04, 2021, from https://www-statista-com.proxy.lib.pdx.edu/statistics/1219452/hong-kongsecurities-market-turnover-at-the-hkex/

Ho, K. (2021, January 10). Skin in the Game: Hong Kong protesters facing security law see banned slogan tattoos as 'last inch of freedom'. Hong Kong Free Press. https://hongkongfp.com/2021/01/10/skin-in-the-game-hong-kong-protesters-facing-securitylaw-see-banned-slogan-tattoos-as-last-inch-of-freedom/.

Hoare J. (2000). The Era of the Unequal Treaties, 1858-99. In: Nish I., Kibata Y. (eds) The History of Anglo-Japanese Relations. The History of Anglo-Japanese Relations, 1600-2000. Palgrave Macmillan, London. https://doi.org/10.1057/9780230598959_5

Huang, H., \& Duhalde, M. (2019, July 4). History of Hong Kong Protests: Riots, rallies And brollies. South China Morning Post. https://multimedia.scmp.com/infographics/news/hongkong/article/3016815/hong-kong-protest-city/index.html.

Hui, M. (2021, July 5). A soy milk company is feeling the pain of Hong Kong's LATEST Flashpoint with Beijing. Quartz. https://qz.com/2029380/vitasoy-faces-china-boycott-in-latest-hong-kongbeijing-spat/

IMF. (2021, April 6). Gross domestic product (GDP) at current prices in Hong Kong from 2010 to 2020 with forecasts until 2026 (in billion U.S. dollars and Hong Kong dollars) [Graph]. In Statista. Retrieved August 08, 2021, from https://www-statistacom.proxy.lib.pdx.edu/statistics/316972/hong-kong-gross-domestic-product/ 
IMF, \& National Bureau of Statistics of China. (2021, April 6). Total population of China from 1980 to 2020 with forecasts until 2026 (in millions) [Graph]. In Statista. Retrieved August 10, 2021, from https://www-statista-com.proxy.lib.pdx.edu/statistics/263765/total-population-of-china/

Ives, M. (2019, June 10). What is Hong Kong's extradition bill? The New York Times. https://www.nytimes.com/2019/06/10/world/asia/hong-kong-extradition-bill.html.

Lee, Y. N. (2020, June 18). These charts show why Hong Kong is important to China. CNBC. https://www.cnbc.com/2020/06/18/these-charts-show-why-hong-kong-is-important-tochina.html

Leung, M. (2016). 'One country, two systems', 'one city, two systems': Citizenship as a stage for politics of mobility and bordering practices in Hong Kong. Migration Letters, 13(1), 49-63.

Retrieved from http://stats.lib.pdx.edu/proxy.php?url=http://search.proquest.com.proxy.lib.pdx.edu/docview/ $\underline{1823858100}$ ?accountid=13265

Li, J. (2000). Power, money, and media: communication patterns and bureaucratic control in cultural China. Northwestern University Press.

Lim, T. W. (2015). The aesthetics of Hong Kong's "Umbrella Revolution" in the first ten days: A historical anatomy of the first phase (27 Oct 2014 to 6 October 2014) of Hong Kong's Umbrella Revolution. East Asia, 32(1), 83-98. https://doi-org.proxy.lib.pdx.edu/10.1007/s12140-014$\underline{9223-1}$

Ma, N., \& Cheng, E. W. (Eds.). (2019). The umbrella movement: Civil resistance and contentious space in 
hong kong. ProQuest Ebook Central https://ebookcentral-proquest-com.proxy.lib.pdx.edu

Marsh, J. (2021, June 24). Hong Kong's biggest pro-democracy NEWSPAPER closes as Beijing tightens its GRIP | CNN BUSINESS. CNN. https://www.cnn.com/2021/06/23/media/apple-daily-closure-intlhnk-dst/index.html.

McMorrow, R. W. (2015, December 19). Membership in the communist party of China: who is being admitted and how? JSTOR DAILY. https://daily.jstor.org/communist-party-of-china/.

Mengin, F., Rocca, Jean-Louis, \& Fondation nationale des sciences politiques. Centre d'études et de recherches internationales. (2002). Politics in China : moving frontiers. Palgrave Macmillan.

Miners, N. (1986). The government and politics of Hong Kong (4th ed.). Oxford University Press.

Ministry of Foreign Affairs Taiwan. (2021). History. Government Portal of Republic of China, Taiwan. https://www.taiwan.gov.tw/content_3.php.

National Bureau of Statistics of China. (October 15, 2020). Gross domestic product (GDP) of China in 2019, by region (in billion yuan) [Graph]. In Statista. Retrieved August 11, 2021, from https://www-statista-com.proxy.lib.pdx.edu/statistics/278557/gdp-of-china-by-region/

Pomfret, J., \& Jim, C. (2019, December 31). Exclusive: Hong KONGERS support protester demands; minority wants independence from China - Reuters poll. Reuters. https://www.reuters.com/article/us-hongkong-protests-poll-exclusive/exclusive-hong-kongerssupport-protester-demands-minority-wants-independence-from-china-reuters-pollidUSKBN1YZOVK.

PwC. (March 5, 2021). Number of listed companies in Greater China in 2020, by stock exchange [Graph]. 
In Statista. Retrieved August 04, 2021, from https://www-statista-

com.proxy.lib.pdx.edu/statistics/234364/number-of-listed-companies-in-greater-china-by-stockexchange/

Ramzy, A., Yu, E., \& May, T. (2020, October 01). On China's National Day, Hong Kong Police Quash Protests. Retrieved October 24, 2020, from https://www.nytimes.com/2020/10/01/world/asia/hong-kong-protests-china.html

Rodrigue, J.-P. (2020). China's special economic zones. The Geography of Transport Systems. https://transportgeography.org/contents/chapter7/globalization-international-trade/specialeconomic-zones-china/.

SCMP. (2021). A simple guide to the Chinese government. SCMP.

https://multimedia.scmp.com/widgets/china/cpc-primer/.

SCMP. (2021). Beijing clamps down on Hong Kong brand Chickeeduck, citing design 'advocates violence.'

SCMP. https://www.youtube.com/watch?v=2BFVqkppUpU.

Securities and Futures Commission HK. (August 31, 2020). Number of yuan-denominated investment products in Hong Kong from 2016 to 2020 [Graph]. In Statista. Retrieved August 04, 2021, from https://www-statista-com.proxy.lib.pdx.edu/statistics/1230405/hong-kong-number-of-yuaninvestment-products/

Securities and Futures Commission HK. (August 31, 2020). Value of yuan-denominated investment products in Hong Kong from 2016 to 2020 (in billion yuan) [Graph]. In Statista. Retrieved August 04, 2021, from https://www-statista-com.proxy.lib.pdx.edu/statistics/1230413/hong-kongvalue-of-yuan-investment-products/ 
Shanghai Municipal Statistics Bureau. (March 19, 2021). Gross domestic product (GDP) of Shanghai municipality in China from 2010 to 2020 (in billion yuan) [Graph]. In Statista. Retrieved August 08, 2021, from https://www-statista-com.proxy.lib.pdx.edu/statistics/802355/china-gdp-ofshanghai/

Sing, M. (2004). Hong kong's tortuous democratization: A comparative analysis. ProQuest Ebook Central https://ebookcentral-proquest-com.proxy.lib.pdx.edu

Sito, P. (2018, March 9). At 94, is Hong Kong's rubber DUCK man the OLDEST start-up guy? South China Morning Post Business. https://www.scmp.com/business/companies/article/2136075/howrubber-duck-hong-kongs-business-and-spirit-can-do.

Statistics Bureau of Shenzhen Municipality. (April 23, 2021). Annual growth rate of the gross domestic product (GDP) of Shenzhen city, China from 2010 to 2020 [Graph]. In Statista. Retrieved August 04, 2021, from https://www-statista-com.proxy.lib.pdx.edu/statistics/1025245/china-gdp-yearon-year-change-of-shenzhen/

Statistics Bureau of Shenzhen Municipality. (April 23, 2021). Gross domestic product (GDP) at current prices of Shenzhen city in China from 2010 to 2020 (in billion yuan) [Graph]. In Statista. Retrieved August 08, 2021, from https://www-statistacom.proxy.lib.pdx.edu/statistics/1025207/china-gdp-of-shenzhen/

So, A. Y. (2011). "One country, two systems" and Hong Kong-China national integration: A crisistransformation perspective. Journal of Contemporary Asia, 41(1), 99-116. https://doiorg.proxy.lib.pdx.edu/10.1080/00472336.2011.530039

Tai, B. Y. (2019). Stages of Hong Kong's democratic movement. Asian Journal of Comparative 
Politics, 4(4), 352-380. https://doi-org.proxy.lib.pdx.edu/10.1177/2057891118815777

The Editors of Encyclopaedia Britannica. (2020). Great leap forward. Encyclopædia Britannica. https://www.britannica.com/event/Great-Leap-Forward.

Tsoi, G., \& Wai, L. C. (2020, June 30). Hong Kong security law: What is it and is it worrying? BBC News. https://www.bbc.com/news/world-asia-china-52765838.

Tsui-kai, W. (2019, November 29). Hong Kong protests: What are the 'five demands'? What do protesters want? Young Post. https://www.scmp.com/yp/discover/news/hongkong/article/3065950/hong-kong-protests-what-are-five-demands-what-do.

van Kemenade, W. (1998). China, Hong Kong, Taiwan, Inc. Little, Brown.

Wai, L. C. (2019, October 11). Why Starbucks? The brands being attacked in Hong Kong. BBC News. https://www.bbc.com/news/world-asia-china-49983767.

Wang, V. (2021, January 8). Protesters given prison terms for beating reporter at Hong Kong airport. The New York Times. https://www.nytimes.com/2021/01/08/world/asia/hong-kong-protestsairport.html.

Wang, V., Ramzy, A., \& May, T. (2020, May 24). Hong Kong police fire tear gas as Protesters Resist China's Grip. The New York Times. https://www.nytimes.com/2020/05/24/world/asia/hongkong-protest-coronavirus-china.html.

Xinhua News Agency, \& State Council Information Office (China). (2021, June 30). Number of Chinese Communist Party (CCP) members in China from 2010 to 2021 (in millions) [Graph]. In Statista. Retrieved August 11, 2021, from https://www-statista- 
com.proxy.lib.pdx.edu/statistics/281378/number-of-chinese-communist-party-ccp-members-inchina/

Zeng, Z. (2015, April 14). Global experiences with special economic zones: focus on China and Africa. World Bank. https://documents.worldbank.org/en/publication/documentsreports/documentdetail/810281468186872492/global-experiences-with-special-economiczones-focus-on-china-and-africa.

Wang, V., \& Dong, J. (2021, March 20). Hong Kong, its Elections Upended, Reconsiders its dream of democracy. The New York Times. https://www.nytimes.com/2021/03/20/world/asia/hongkong-elections-democracy.html.

Zhang, B. (2011). Democratizing Hong Kong: functional representation and politics of institutional change. Pacific Affairs, 84(4), 643. https://link.gale.com/apps/doc/A283705623/AONE?u=s1185784\&sid=AONE\&xid=b1c28d9f 